\title{
Effects of renewable energy on landscape in Europe: Comparison of hydro, wind, solar, bio-, geothermal and infrastructure energy landscapes
}

\author{
Marina Frolova ${ }^{1}$, Csaba CENTERI ${ }^{2}$, Karl BENEDiKTSSON ${ }^{3}$, Marcel HUNZIKER ${ }^{4}$, \\ Robert KABAI ${ }^{5}$, Alessandra SCOGNAMIGLIO ${ }^{6}$, Georgios MARTINOPOUlOS 7 , \\ Georgia SISMANI ${ }^{8}$, PAulo BRITO ${ }^{9}$, Emilio MUÑOZ-CERÓN ${ }^{10}$, MAteusz SŁUPIŃSKI11, \\ Michela GHISLANZONI ${ }^{12}$, Dominik BRAUNSCHWEIGER ${ }^{13}$, \\ DANiel HERRERO-LUQUE ${ }^{14}$ and Michael ROTH ${ }^{15}$
}

\begin{abstract}
Landscape quality has become a fundamental issue in the development of renewable energy (henceforth abbreviated RE) projects. Rapid technological advances in RE production and distribution, coupled with changing policy frameworks, bring specific challenges during planning in order to avoid degradation of landscape quality. The current work provides a comprehensive review on RE landscapes and the impacts of RE systems on landscape for most European countries. It is based on a review by an interdisciplinary international team of experts of empirical research findings on landscape impacts of RE from thirty-seven countries that have participated in the COST Action TU1401 Renewable Energy and Landscape Quality (RELY).
\end{abstract}

Keywords: landscape impacts, renewable energy, energy transition, landscape quality

${ }^{1}$ Department of Regional and Physical Geography and Institute for Regional Development, University of Granada, Campus de Cartuja s/n, 18071 Granada, Spain. Corresponding author's e-mail: mfrolova@ugr.es

${ }^{2}$ Department of Nature Conservation and Landscape Ecology, Institute of Nature Conservation and Landscape Management, Faculty of Agricultural and Environmental Sciences, Szent István University, Páter Károly u. 1., H-2100 Gödöllő. E-mail: centeri.csaba@mkk.szie.hu

${ }^{3}$ Department of Geography and Tourism, Faculty of Life and Environmental Sciences, University of Iceland, 101 Reykjavík, Iceland. E-mail: kben@hi.is

${ }^{4}$ Social Sciences in Landscape Research Group, Research Unit Economics and Social Sciences, Swiss Federal Research Institute WSL, CH-8903 Birmensdorf. E-mail: marcel.hunziker@wsl.ch

${ }^{5}$ Hunscapes Ltd. Hunscapes Ltd., Petur u. 37. H-1031 Budapest. E-mail: robert.kabai@hunscapes.hu

${ }^{6}$ ENEA, Energy Technologies Department, Photovoltaics and Smart Devices Division, Innovative Devices Laboratory. Largo Enrico Fermi 1, 80055 Portici (NA), Italy. E-mail: alessandra.scognamiglio@enea.it

${ }^{7}$ School of Science and Technology, International Hellenic University, EL-57001 Thessaloniki.

E-mail: g.martinopoulos@ihu.edu.gr

${ }^{8}$ Department of Civil Engineering, Aristotle University of Thessaloniki, EL-54124 Thessaloniki.

E-mail: gsismani@civil.auth.gr

${ }^{9}$ Polytechnic Institute of Portalegre, Campus Politécnico 10, 7300-555 Portalegre, Portugal. E-mail: pbrito@estgp.pt

${ }^{10}$ Department of Graphic Engineering, Design and Projects and Centre for Advanced Studies in Energy and Environment, University of Jaen, Campus Las Lagunillas s/n, 23071 Jaén, Spain. E-mail: emunoz@ujaen.es

${ }^{11}$ Centre for System Solutions, Jaracza 80b/10, 50-305 Wroclaw, Poland. E-mail: mateusz.slupinski@crs.org.pl

${ }^{12}$ Territoria, AyGM SL, Seville, Spain. E-mail: mg@territoria.es

${ }^{13}$ Regional Economics and Development Research Group, Research Unit Economics and Social Sciences, Swiss Federal Research Institute WSL, CH-8903 Birmensdorf. E-mail: dominik.braunschweiger@wsl.ch

${ }^{14}$ Department of History, Geography and Communication, Faculty of Humanities, University of Burgos, Paseo de los Comendadores s/n, 09001 Burgos, Spain. E-mail: dhluque@ubu.es

${ }^{15}$ Nürtingen-Geislingen University, School of Landscape Architecture, Environmental and Urban Planning, Schelmenwasen 4-8, 72622 Nürtingen, Germany. E-mail: michael.roth@hfwu.de 


\section{Introduction}

Over the last two decades many European countries have adopted and implemented policies in order to initiate a transition to more sustainable energy systems (European Commission 2009). This energy transition is based on different kinds of renewable energy (abbr. RE) and associated systems. All these RE systems have transformed land use and, in many cases, reshaped the landscapes of Europe. RE has generally lower energy densities than other sources, requiring more surface area to produce an equivalent amount of power as non-RE systems (VAN ZaLK, J. and BeHRens, P. 2018) and their relative visual impact is often higher (Wolsink, M. 2007). Therefore, their impact on landscape quality has become a fundamental issue in the development of RE projects. Local opposition based on landscape issues has significantly limited the growth of the RE sector in Europe (UPRETI, B.R. and VAN Der Horst, D. 2004; Wolsink, M. and Breukers, S. 2010; Devine-Wright, P. and Batel, S. 2017). In addition, rapid technological advances in the production and distribution of $\mathrm{RE}$, coupled with changing policy frameworks bring specific challenges for energy planning to avoid the degradation of landscape quality.

Each RE system transforms the landscape in a specific way, therefore it can affect landscape quality in different forms. In addition to the type of RE, the impact also varies depending on the context and scale of development and the methods used (BENEDiKTsson, K. et al. 2018).

The main research questions were: (1) What are the geographical patterns of development of different forms of RE and landscapes associated with them in Europe? (2) What is the state of knowledge on landscape impacts of RE infrastructures in Europe and on different types RE landscapes? (3) How should be RE systems planned for converting a landscape with elements of energy chain into sustainable energy landscape? (4) What are the common features and differences between landscape impacts of hydro, wind, solar, bio and geothermal energies, and associated energy infrastructures?
Objectives of this paper are:

1. to explore the state of REs development in Europe that shows distribution of development of REs and thus extension of RE landscapes in Europe,

2. to provide a comprehensive review on landscape impacts of each RE system type,

3. to explore different characteristics of six RE landscape types that should be carefully planned in order to shape sustainable energy landscapes.

\section{Theoretical background}

A growing number of studies on different kinds of renewables (Pasqualetti, M.J. 2013; Bakken, T.H. et al. 2014; Frolova, M. et al. 2015a, b; Solomon, B.D. and Barnett, J.B. 2017; Pasqualetti, M. and Stremke, S. 2018; Rотн, M. et al. 2018) has highlighted their impacts on landscapes and their quality. Energy landscape has become a recognized landscape type, defined as a multi-layer landscape characterized by one or more elements of the energy chain comprising combinations of technical and natural sources of energy within a landscape. Energy landscapes are best understood in terms of their multiple spatiality, including material and immaterial dimensions (CALVERT, K. et al. 2019).

In this paper we study hydro, wind, solar, bio- and geothermal landscapes. Their spatial qualifications are based on the amount of space required for energy development and on spatial dominance (Pasqualetti, M. and Stremke, S. 2018). Renewable energy infrastructure creates a 'component' or 'layer' type, and 'entity' type of energy landscape. The 'component' or 'layer' type of landscape may require a large commitment of land. In 'entity' type landscapes, energy production presents the predominant land use. As the authors claim 'entity' energy landscapes require substantially different decision-making processes compared with 'component' energy landscapes. Finally, an ensemble of auxiliary elements referred to assimilation, conversion, storage, transport or transmission of 
energy produced is considered as 'infrastructure energy landscapes' (UYTERLINDE, M. et al. 2017), spatially unique, largely empty entities within which other land uses are rarely possible (Pasqualetti, M. and Stremke, S. 2018).

RE landscapes are dynamic systems, shaped both by natural evolution of landscape and constantly changing societal needs. In this sense, it is important to take into consideration the evolving character of perceptions of RE landscapes. As any landscape, energy landscapes are also shaped by the perceptions of the people who use, share and value them (Olwig, K.R. 2007). Several studies have shown that whether the perception of these landscapes will be positive or negative depends not only on its characteristics, but also on the 'genius loci' shaped by relation between local people and their territory and resources, and reflects multiple layers, systems of values, aspirations and beliefs, associated to these landscapes (Frolova, M. 2017; BevK, T. and Golobič, M. 2018).

The paper focuses on different aspects of $R E$ effects on landscape with the aim of advancing the conceptual framework for RE landscape. We analyze the material sub-systems of the RE landscape which are related to the extraction and use of energy resources. Only if these sub-systems are carefully adapted to the other landscape sub-systems, landscape structure and functions, landscape quality is not affected and could be even improved. Therefore, a comparative analysis of RE effects on landscape is crucial for energy planning and for shaping sustainable energy landscapes. We explore both the substantive and spatial characteristics of RE landscapes in order to understand the scope of effects of RE infrastructures and the ways to avoid their negative impacts and to enhance their positive landscape effects.

Landscape impact is understood in this paper as the effect of RE systems on the physical landscape. Landscape impacts of RE systems can be negative or positive, permanent or temporary, primary or secondary; they can be accumulative and can arise at different scales (BELL, S. 2017). They also vary in nature and scale. These effects include both potential changes that arise to landscape character and available views in a landscape from a RE facility. Beyond the direct landscape impact of the RE facilities, there are potentially various negative environmental impacts with an influence on landscape character.

In this paper, we differentiate three groups of landscape-related impacts: 1 . direct impacts on visual and aesthetical characteristics of landscape, 2. effects related with land use changes, 3 . indirect landscape impacts related to environmental issues.

\section{Materials and methods}

This paper is based on literature review collected by a team of experts from the 37 COST countries. A map and a table were prepared that provide a European overview of production from hydro, wind, solar, bio- and geothermal sources, as well as the share of RE in energy consumption.

Secondly, a comparison was made of the state of knowledge on landscape impacts of different RE technologies, and some most commonly mentioned impacts and their mitigation strategies were described.

The data on RE utilization and electricity production capacities in the COST actionmember countries were complemented with quantitative analysis on power density of land use efficiency for each RE source. Since there were no comparable data on their value for each type of RE in the European countries, we used estimations of VAN ZALK, J. and BEHRENS, P. (2019) and Trainor, A.M. et al. (2016). VAN ZaLK, J. and Behrens, P. (2019) calculated power densities for solar, wind, geothermal, hydro, and biomass, including consideration on the total footprint, efficiency and/or capacity factor. Trainor, A.M. et al. (2016) calculated the area of direct footprint for each RE type.

Finally, some essential characteristics, and those direct and indirect landscape impacts of $\mathrm{RE}$ of each landscape type that have been most discussed in the literature, were compared specifying sub-types of some RE landscapes. 


\section{Overview of renewable energy landscapes in Europe and their landscape impact}

The literature on the impacts of RE systems is vast. Papers on hydropower have lost their earlier predominance, and studies of wind and solar energy now prevail. Studies of bioenergy impacts are growing in number. According to the reviewed papers, the most controversial RE system in terms of direct landscape effects is wind (Рiсchi, P. et al. 2019), followed by solar energy. In terms of environmental impacts and effects on land use, the most discussed RE system is bioenergy.

Figure 1 shows all forms of usable RE, including primary production in each country by type and total share in consumption. Table 1 focuses only on electricity production capacities, specifying sub-types of some REs and provides data for tidal, wave and ocean energy in addition to the types mentioned above, based on 2016 data from the EU statistical office.

Certain clarifications and reservations need to be made regarding these data. For some RE sources, the production of energy can take several forms. This is especially the case regarding energy from biological sources, which is produced in various forms (solid, liquid or gas). The Eurostat database reports all these categories and they are included in the total figure, which is used as a basis for bioenergy on the map.

For solar energy, the Eurostat database reports two forms: photovoltaic (abbr. PV) and thermal. The latter, however, includes both electrical production and the direct production of hot water for domestic use. These two forms are shown together on the map. Likewise,

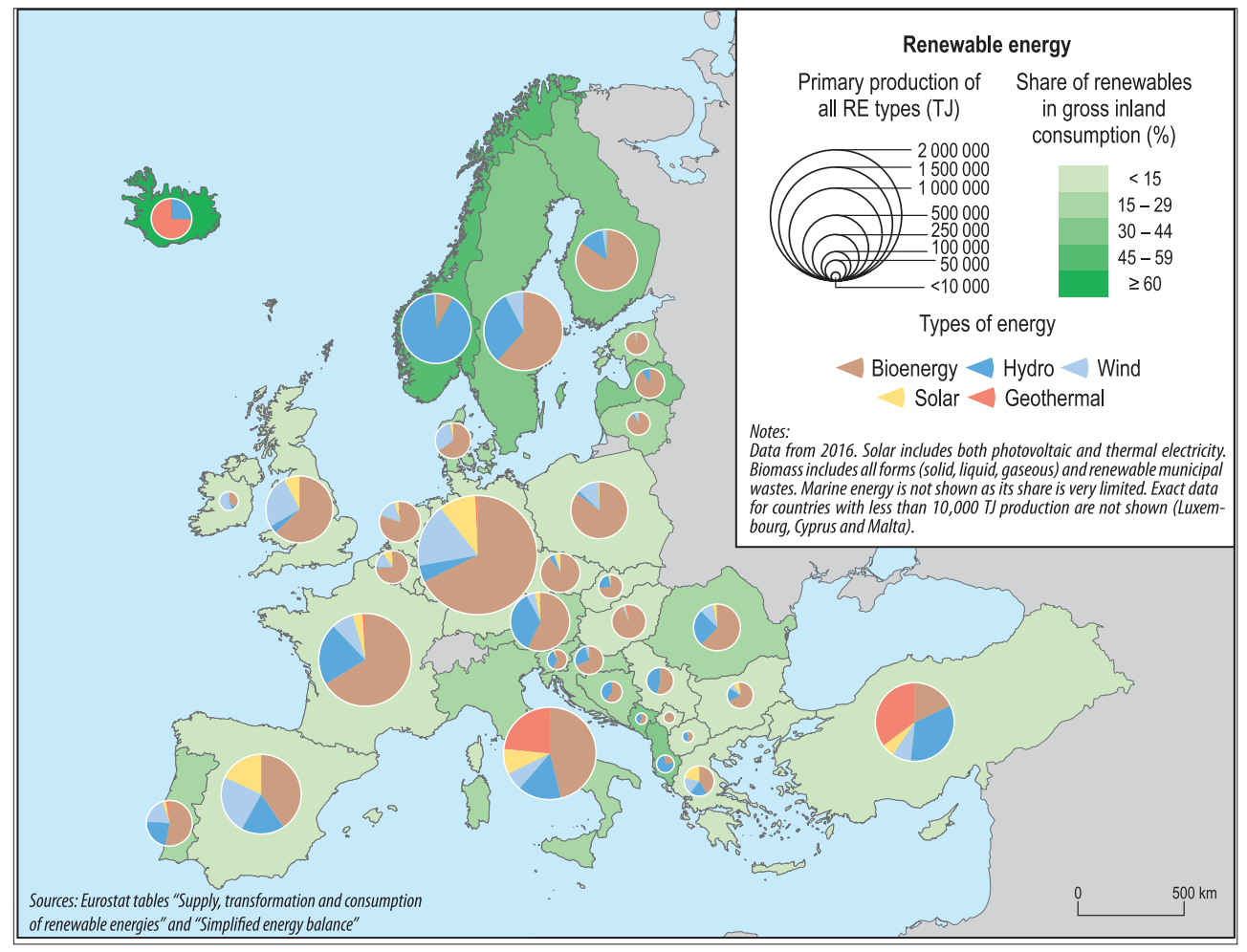

Fig. 1. Renewable energy utilization in Europe, 2016. Compiled by Benediktsson, K., Herrero-Luque, D., Kabai, R., Sismani, G. and SŁupiński, M. Data source: Eurostat, BFE Switzerland. 


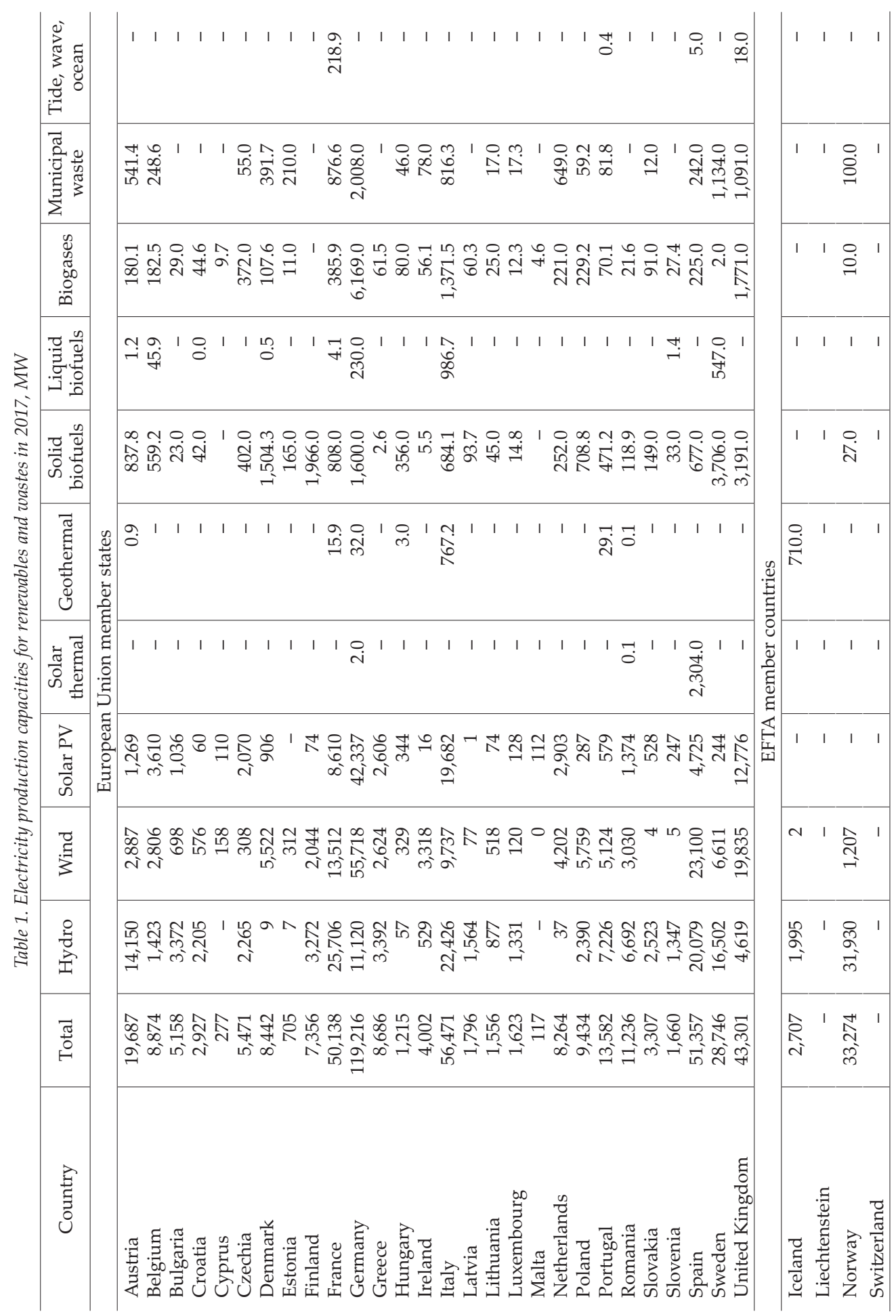




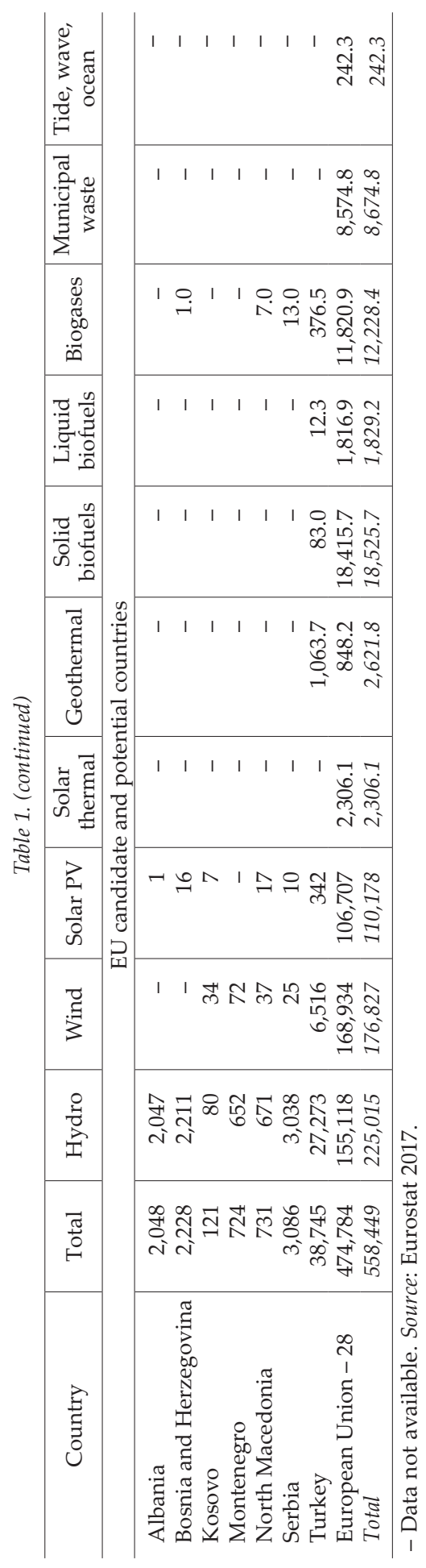

geothermal energy (abbr. GE) is utilized in two distinct forms - directly as hot water and through conversion to electricity. The map shows them combined. Indeed, the Eurostat database does not distinguish between these forms. For the thermal part of GE, reliable and fully comparable statistics are hard to find. The map and the table give a good indication of the overall state of RE in Europe (in 2016 and 2017), and the considerable geographical diversity that exists in terms of RE development. It will serve as a reference point for the discussion of individual RE sources, their main characteristics and landscape impacts.

Generally, the geographical patterns of development of different types of RE systems match with the geography of studies on their landscape impacts.

\section{Hydro energy landscape}

Hydro energy landscapes are the best established among RE landscapes, probably due to the long history of development of hydro power. Hydro energy is the most mature technology that harnesses RE and the second most important source in Europe, representing 22 per cent of all RE. Norway leads in terms of absolute production, while its production is rather insignificant in Germany, Czech Republic, and the UK, and almost absent in countries where the topography is not conductive: Poland, Hungary and Denmark (see Figure 1).

The European Commission and the European Small Hydropower Association have set a threshold of $10 \mathrm{MW}$ installed power for distinguishing between small and large hydropower plant (abbr. SHP and LHP) (European Commission 2015). In 2010 nearly 21,800 SHPs were in operation within Europe (Frolova, M. et al. 2015c). Nevertheless, in 201190 per cent of installed capacity in Europe was still made up of LHPs (European Commission 2013). Only Austria relies more heavily on SHPs by 16 per cent of total nationwide capacity of hydropower plants.

The hydropower landscape is based on collection of water and utilization of potential 
energy to generate electricity (PAsqualetti, M. and StremKe, S. 2018). Although it is often associated with dams as a key element, several types of hydropower plants exist: hydroelectric dams, pumped-storage plants, runof-river plants and tidal plants. Additionally, hydropower plants are often classified according to their energy production capacity. Exact definitions and thresholds can be somewhat arbitrary (Frolova, M. 2017).

The impacts of hydropower developments depend on type, size and the landscape in which it is placed. Average power density of hydropower systems varies extensively from $0.01 \mathrm{~W}_{\mathrm{e}} / \mathrm{m}^{2}$ to $0.11 \mathrm{~W}_{\mathrm{e}} / \mathrm{m}^{2}$ in large facilities with reservoirs and up to $0.75 \mathrm{~W}_{\mathrm{e}} / \mathrm{m}^{2}$, in case of large run-of-river plants (VAN ZALK, J. and Behrens, P. 2019). While the average direct footprint was estimated as $16.86 \mathrm{~km}^{2} / \mathrm{TWhr}$, it varies greatly from 6.45 to $86.95 \mathrm{~km}^{2} / \mathrm{TWhr}$ (Trainor, A.M. et al. 2016). Due to the varied power density of hydropower plants, differences in the spatial extent of different types of facilities, and the visual dominance of hydroelectric energy infrastructures, hydropower landscapes offer a great variety of 'components' or 'layers', in case of SHP, and 'entity energy landscapes' in case of LHP.

Land use impacts are mentioned only in the context of flooded area and creation of artificial reservoirs.

It is commonly accepted that negative landscape effects of large facilities could derive from construction of power stations, damming rivers, and creating artificial reservoirs (Cohen, J.J. et al. 2014; Hastik, R. et al. 2015). In addition, in LHPs, dams, power stations and transmission lines are huge structures and their presence constitutes substantial change in landscape features (Hastik, R. et al. 2015). The river flow fluctuation caused by hydropower plants results in dramatic changes in downstream ecosystems and sometimes in the landscapes of entire river basins (Frolova, M. 2010).

Landscape impacts of SHPs are different, and considered relatively small. They often utilize natural differences in altitude, small flows or the decline in the pipes from water infrastructure to provision of power for small communities. SHPs also often utilize run-ofthe-river designs, which may require a small, less obtrusive dam, diverts a portion of a river's water into a canal or pipe to spin turbines. Consequently, run-of-the-river designs have risen in popularity lately. Nevertheless, individual SHPs cover large areas and most of their infrastructure is usually visible from the surface while some of the infrastructures of LHPs are located underground. Therefore, the negative landscape impact of a large number of SHPs could exceed that of one LHPs with equivalent output (АвваsI, T. and АвваSI, S.A. 2011; Koutsoyiannis, D. 2011; BaKKen, T.H. 2014).

Diversion for electricity generation can lead to drying up of large watercourses and the damming of rivers can lead to the erosion of the shoreline, therefore damaging soil and biota. Increased water discharge causes a bigger riverbank erosion downstream (Rosenberg, D.M. et al. 1995). Rapid flow variations due to hydro power plants can affect both physical and chemical qualities of water (Cushman, R.M. 1985; Evans, A. et al. 2009). These drastic changes in water-related ecosystems (Cushman, R.M. 1985; ČADA, G.F. 2001; Evans, A. et al. 2009) threaten fish populations and various other species.

However, LHPs have also positive landscape impacts. Large dams and artificial lakes can generate positive visual impact and become regional attractions, boosting tourism and local income (Frolova, M. 2010; Hastik, R. et al. 2015).

Many adverse impacts of hydro power plants can be mitigated, e.g. fish ladders can help to mitigate the impact (ČADA, G.F. 2001). Furthermore, utilizing existing infrastructure for the construction of SHPs may help to reduce their negative impact on the landscape (STEvović, S. et al. 2014). Landscape impacts of LHPs may be reduced by establishing reservoirs from natural lakes (BAKKEN, T.H. 1014).

Perception of visual impacts of both large and small hydro power systems may depend on the original state of the landscape and its cultural value. The social norms concerning these landscape aesthetics has been evolving 
over generations, and became an important type of landscape in many European countries (Frolova, M. 2017; Benediktsson, K. et al. 2018).

\section{Wind energy landscape}

Wind energy landscapes are also relatively common in Europe. It supplies about 11 per cent of RE as illustrated in Figure 1. In Denmark, the United Kingdom, and Spain, the share of wind in RE is highest. It is lower in Germany, which is, however, the largest single producing country, followed by Spain, the UK and France (see Table 1). Large-scale commercial offshore wind farms (abbr. WFs) have been developed in many European coastal countries, in particular in the UK, Germany, Denmark, Belgium, the Netherlands and Sweden.

Wind energy harnessing is based on using kinetic energy to pump water, process materials or to produce electricity (PAsqualetti, M. and Stremke, S. 2018). WFs consist of several individual wind turbines connected to the electric power transmission network. The most prominent elements of wind energy landscapes are the towers and turning blades of wind turbines. Usually WFs are classified as small or large based on the number of turbines and their capacity. Ruggiero, F. and ScAletta, G. (2014) classify onshore wind farms: large $(1+$ turbines, $1<\mathrm{MW})$, medium size (single turbine, 0.5-1.0 MW), "miniwind" $(1+$ turbine, $<0.5 \mathrm{MW})$, and "micro-eolic" (single turbine, $<0.01 \mathrm{MW}$ ). The footprint increases essentially for capacity larger than 1 MW (van Zalk, J. and Behrens, P. 2019). Only about 3 per cent of land used for wind development is directly impacted by turbines and wind energy infrastructures, and the total area required includes the land in between the turbines (Trainor, A.M. et al. 2016), although this land can be used for agriculture, etc. Given the fragmenting effect on animal habitats, its ecological impact spreads on this total area required. Therefore, the indirect landscape impact affects a much larger area. While the average direct footprint of onshore wind farms is estimated as $16.86 \mathrm{~km}^{2} / \mathrm{TWhr}$ (6.45-86.95 km²/TWhr, depending on installed capacity), the indirect landscape impact has been estimated as $126.92 \mathrm{~km}^{2} /$ TWhr (Idem.).

Offshore winds generally flow at higher speeds due to reduced interference from topography, vegetation and the built environment, thus turbines can produce more electricity than onshore and at a lower height (BILGILI, M. et al. 2011). In addition, there is a considerable difference in average power densities for onshore $(\mu$ $\left.=3.1 \pm 0.7 \mathrm{~W} / \mathrm{m}^{2}\right)$ and offshore $(\mu=4.2 \pm 1.7 \mathrm{~W} /$ $\mathrm{m}^{2}$ ) wind farms; the latter requires less surface area to produce an equivalent amount of power (van Zalk, J. and Behrens, P. 2019).

Landscape issues have always been crucial in wind power development (Wolsink, M. 2007; Toke, D. et al. 2008; Strachan, P. et al. 2009; Pasqualetti, M.J. 2011). This landscape was one of the first RE landscape recognized as such by researchers (MölleR, B. 2010; SснӧвEL, S. et al. 2012). Among the numerous studies on landscape impacts of onshore WFs, the main focus is their visual/aesthetic impact, although the impact on landscape functions and structure of large- or numerous small-scale WFs (Photo 1) are also important concerns (Hurtado, J.P. et al. 2004; Wolsink, M. 2007; Möller, B. 2010; Scottish Natural Heritage 2014). Indirect landscape impacts related to environment are also frequently discussed (Wolsink, M. 2007; MEDDE 2010), and land-use impacts are also considered as important issues for large-scale developments (Scottish Natural Heritage 2014).

Wind energy landscapes are characterized by visually disturbing height $(\sim 160 \mathrm{~m})$ of wind turbines. A number of researchers emphasize that landscape impact of WFs is strongly influenced by the size, design and layout of wind parks, and also vary with the make and model of the turbine (RugGiero, F. and Scaletta, G. 2014; Scottish Natural Heritage 2014). It also depends on the cumulative impact of multiple WFs, which requires not only environmental impact assessment (abbr. EIA), but also strategic spatial planning. Finally, landscape perception of WFs could also be affected by other dynamic 


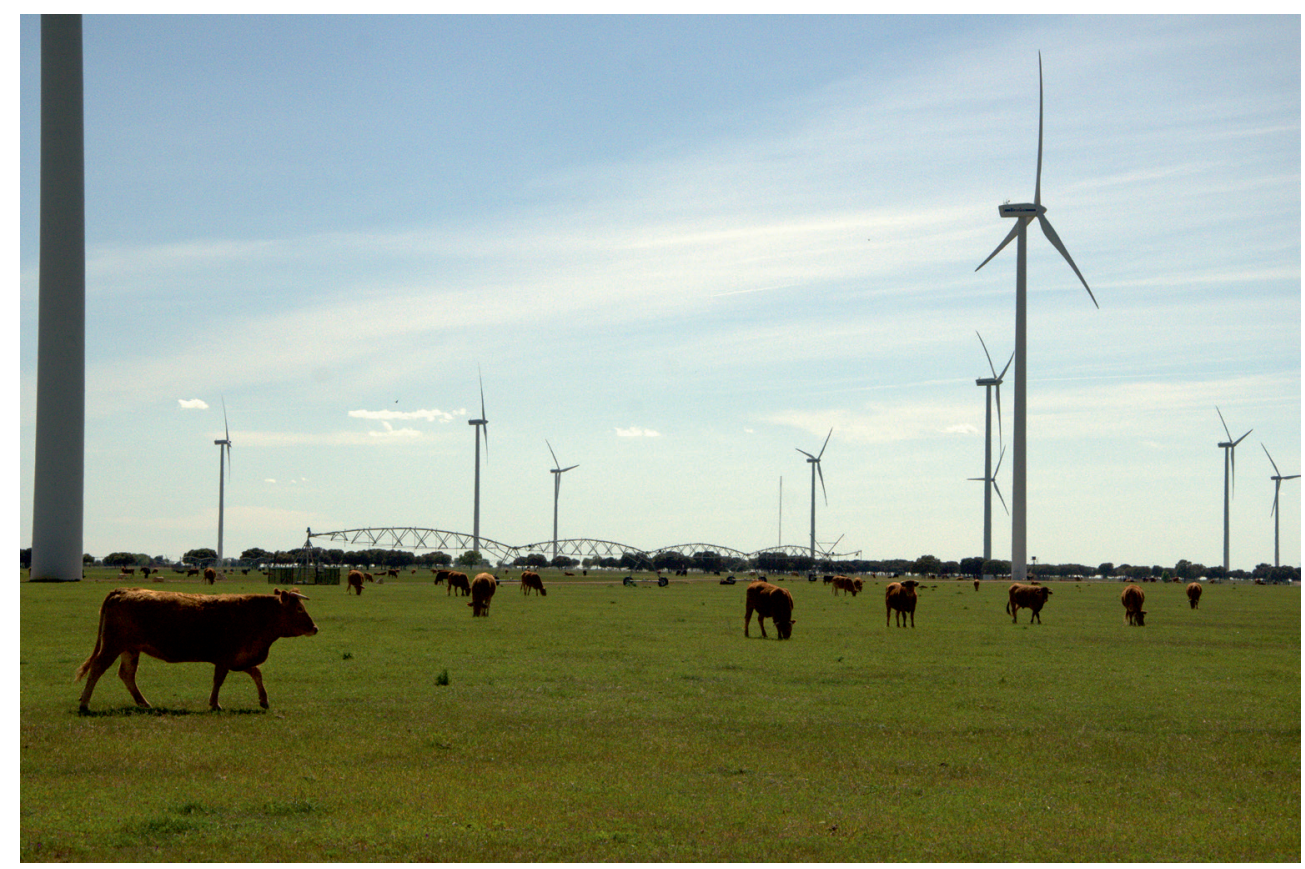

Photo 1. Wind farm "San Lorenzo", Castilla y Leon, Spain (Photo by Herrero, D.)

factors, such as night lights, shadow flicker and the stroboscopic effect (KIL, J. 2011).

The appearance of wind energy landscape depends on how the wind turbine is positioned in the landscape, the type of landscape, the wind turbine's size, and the proximity of the observer (Danish Energy Agency 2009).

Land use issues are also important because of requirement of a large commitment of land for WFs developments. However, they allow other concurrent uses of that land (Pasqualetti, M. and Stremke, S. 2018). Due to their compatibility with other land uses, their effect on spatial characteristics of landscape is not very high, therefore wind energy landscape was conceptualized as 'component' or 'layer' type (Pasqualetti, M. and Stremke, S. 2018). However, land use impacts for WFs are seen as essential (Scottish Natural Heritage 2014).

Although offshore WFs have significantly expanded in the last decades, their landscape impacts have only recently been investigated. Today most offshore WFs are installed near the shore where the water depth is relatively shallow. Landscape impact assessment becomes essential for local communities, considering that the deployment of offshore WFs could become conflicting with other activities (Sismani, G. et al. 2017). Visual impact is considered as the most perceptible direct landscape impact of offshore WFs (LADENBURG, J. 2009; Sullivan, R.G. et al. 2013).

As the distance between an offshore WF and the shore increases, the visual impact is reduced and for more than $8 \mathrm{~km}$ distance the impact is considered negligible (HENDERSON, A.R. et al. 2003). Visual perception of an offshore WF depends on the number and size of turbines, but is also affected by the time of the day (Sullivan, R.G. et al. 2013), the local environmental conditions and the movement of the blades (Bishop, I.D. and Miller, D.R. 2007).

As for the negative landscape onshore WFs impacts linked to environmental issues, they are related to the hazards that they pose to birds and bats, noise pollution, 
and destruction and loss or degradation of natural habitats (WoLsINk, M. 2007; MEDDE 2010; Ruggiero, F. and Scaletta, G. 2014). The indirect negative effects of offshore WFs are noise, impact on the local ecosystem and coastal erosion (TougAARD, J. et al. 2008; Bergström, L. et al. 2014).

Many of the negative landscape impacts of onshore WFs could be reduced by their proper design, layout and location, avoiding their visibility from particularly sensitive viewpoints (Scottish Natural Heritage 2014), technical monitoring, environmental surveys and specific restoration operations (MEDDE 2010).

As for offshore wind developments, their negative impacts could be reduced through appropriate site selection (Lindeboom, H.J. et al. 2011) and the establishment of strategic planning processes (BERGSTRöM, L. et al. 2014).

Although landscape is often cited as an argument in the conflicts that arise around wind energy projects, its relationship with these developments is not always conflictive. From an aesthetic point of view, wind turbines can be perceived as sculptural elements in the landscape, evoke positive association by thematic relation to modern structures, and become associated with technological efficiency, progress, environmental cleanliness and utility (Department of the Environmental, Heritage and Local Government, Ireland 2006). The acceptance of both WF type is strongly affected by any prior experience of locals with wind developments (LADENBURG, J. 2009).

Onshore wind turbines may not be considered as a problem for local inhabitants, but instead they could constitute a positive aspect of the construction of a local landscape and sense of place and affirmation of an identity in a given landscape (Frolova, M. et al. 2015a). The development of a wind farm can act as the stimulus for restoration and/or improvement of land use around the site (Scottish Natural Heritage 2014). Agricultural and grazing exploitation in WFs often generate positive impact in perception of these landscapes. FrantáL, B. et al. (2018) refer to cases of utilization of wind energy landscapes as educa- tional centres and exhibition venues. Other smart practices which improve WFs perception are the following: using wind turbines as observation towers, utilizing their tourist potential and to improve the awareness and image of RE, integration with nature trails or for improving the image of environmentally stigmatized areas (FrantáL, B. 2018).

Finally, offshore wind development may also lead to benefits in the ecosystem, as a consequence of reduced shipping, commercial trawling and dredging. The mitigation of impacts may facilitate the establishment of large areas of seabed, and consequently, the creation of a new habitat (LinNANE, A. et al. 2000; Wilhelmsson, D. et al. 2006; INGER, R. et al. 2009; Wilson, J.C. and Elliott, M. 2009).

\section{Solar energy landscape}

In 2016 this type of energy provided about 6 per cent of all RE. The Mediterranean countries and southern Germany dominate the European solar energy map. Spain and Greece have the highest shares of their RE production from solar energy, and Spain, Germany and Italy have the highest production in absolute terms. The most common solar system for electricity production is PV. Within the EU, Germany and Italy are leading (see Table 1). In the Nordic and Baltic countries and Poland there is very little or no utilization (see Figure 1).

Concentrated solar thermoelectric power (abbr. CSP) is still an uncommon solution. However, Europe has a leading position, since Spain is the world leader in CSP with a total capacity of $2.7 \mathrm{GW}$ out of $4.8 \mathrm{GW}$ installed globally (EurObserv'ER 2017; Río, P. et al. 2018).

Finally, solar thermal systems represent a mature market. The installed capacity has almost doubled in the last decade and at the end of 2015 it reached 47.5 million $\mathrm{m}^{2}$ of solar collectors $\left(32.5<\mathrm{GW}_{\mathrm{th}}\right)(\mathrm{ESTIF}$ 2015). Regarding newly installed capacity, Germany represents almost 40 per cent of the European market, followed by Italy (10\%) and Poland (9\%). The market for combined production of hot water for sanitary uses and 
space heating is well established in Germany and Austria (Mauthner, F. et. al. 2016).

Solar PV landscapes include 2 subtypes: on-ground $P V$ and building added/integrated $P V$. In the first case PV modules arrays are installed optimally oriented to maximize the solar radiation capture, covering significant areas. Its additional landscape impacts are effects from PV arrays, reflecting mirror arrays, and concentrating solar towers for large-scale facilities (Pasqualetti, M. and Smardon, R. 2017). As for the second solar PV topology, PV modules are added (BAPV) or integrated (BIPV) onto/into the building. If the modules are integrated, special PV components are used to perform additional functions than the merely electric generation.

As for CSP landscapes they include four types of systems: parabolic troughs, solar power towers, linear Fresnel concentrators and Stirling parabolic dishes having each of them different effects on landscape (Andrés-Ruiz, C. et al. 2015; Benediktsson, K. et al. 2018).

Finally, space heating and hot water production systems can be found in two topologies: in/on building mounted and on-ground solar thermal. In case of on-ground mounted systems, the number of units requires a larger solar field that cannot be accommodated on the roof of buildings.

In spite of the highest values of power density among solar energies, CSP systems with their $\mu=9.7 \pm 0.4 \mathrm{~W}_{\mathrm{e}} / \mathrm{m}^{2}$ (Idem.), their land use efficiency is lower and the area of direct footprint is higher $\left(19.25 \mathrm{~km}^{2} / \mathrm{TWhr}\right)$ than that of PV systems $\left(15.01 \mathrm{~km}^{2} / \mathrm{TWhr}\right.$ ) (Trainor, A.M. et al. 2016). The variations of area of direct footprint are from 12.30 to $16.97 \mathrm{~km}^{2} / \mathrm{TWhr}$ for solar PV and from 12.97 to $27.98 \mathrm{~km}^{2} /$ TWhr for CSP systems Due to these characteristics and their spatial extent, solar energy landscapes can be seen both as 'component' or 'layer' type or as 'entity energy landscape'.

The landscape impacts of solar power facilities depend significantly on the size of the installations as well as on their concentration in a certain area. Numerous authors analysed landscape impacts of large scale on-ground PV: their land use effects
(Fthenakis, V. and Kim, H.C. 2009; Dijkman, T.J. and Benders, R.M.J. 2010; Horner, R.M. and Clark, C.E. 2013; Lakhani, R. et al. 2014); visual and aesthetic impacts, including glare (Chiabrando, R. et al. 2009; Minelli, A. et al. 2014; Fernandez-Jimenez, L.A. et al. 2015); landscape and habitat fragmentation (Hernandez, R.R. et al. 2014); impacts on ecosystems (HERNANDEZ, R.R. et al. 2014) and soil erosion (Turney, D. and Fthenakis, V. 2011). The negative effects of a massive expansion of large-scale solar systems on landscape can cause an important change in landscape functions and structures (SCOGNAmiglio, A. 2016).

For solar on-ground PV and CSP the concerns about visual impact and land use are more pronounced than for BAPV/BIPV and solar thermal systems, due to the large areas covered (HAsтiк, R. 2015), making the selection of appropriate location crucial (Hernandez, R.R. et al. 2014). As for CSP, the glare effect from the mirrors and metal structures, the visual impact of the tall vertical cooling towers and the columns of steam released into the atmosphere have been acknowledged as the main direct landscape impacts. Impacts related to water issues are also essential, since CSP installations consume large amounts of water and are normally situated in semi-arid areas (ANDRÉs-RuIZ, C. et al. 2015). Finally, the negative impacts on biodiversity of large on-ground PV and CSP is considered an important issue (HERNANDEZ, R.R. et al. 2014; AndrÉs-Ruiz, C. et al. 2015).

Negative effects of solar on-ground and CSP installations on land use can be reduced through a dual use of land for PV and agriculture (RAvi, S. et al. 2016) or grazing (with possible increase of crop production thanks to the shade provided by modules; and possible grass maintenance cost decrease), or for PV and other types of energy production. Artificial water surfaces can be also used to save land (Nordmann, T. et al. 2010; Hernandez, R.R. et al. 2014). Actually, most National RE Action Plans of EU's member states do not encourage the installation of solar farms in high quality cropland (Hernandez, R.R. et al. 2014). 
Some authors suggest that an appropriate mitigating strategy for reducing the solar PV systems visual impact is to integrate them in a landscape and to choose sites with a reduced visibility of $\mathrm{PV}$ installations or integrate them in buildings (CHIABRANDo, R. et al. 2009; KAPETANAKIS, I.A. et al. 2014; Scognamiglio, A. 2016). Nowadays, the implementation of BIPV uses technical solutions and innovative ideas that minimize negative aesthetic impact. Design strategies at the architectural scale have also been suggested for limiting the glare impacts of PV, such as the application of mitigation measures at both reflectors (diffusive reflection coatings) and receptors (plant shadings) (Chiabrando, R. et al. 2009).

Other strategies for generating positive landscape impacts of solar PV systems are the following: (1) The supporting structures of PV can be used as land stabilization elements; (2) The pattern of the PV fields can be designed so as to improve the spatial definition of a certain area (e.g. public parks, bike lanes, walking paths); (3) PV modules can provide shade in spaces where this is needed; (4) PV can be designed so as to meet certain given ecological and landscape objectives (Scognamiglio, A. 2016); (5) Solar PV farms can be also used for conversion of brownfield (underused, abandoned, and often contaminated land) in productive landscape; (6) Large-scale solar parks can be used as educational centres. Finally, solar power is used for the creation of energy roads and roofs (RöHner, S. and Rотн, M. 2018). This versatile character of solar energy landscapes contributes to their positive perception in many European countries (Prados, M.J. 2010; Kontogianni, A. et al. 2013; Tsantopoulos, G. et al. 2014).

\section{Geothermal energy landscapes}

In Europe in 2016, geothermal sources provided almost exactly the same amount of energy as solar sources did. This is the category that has the most uneven distribution of all those described here, due to differences in geological conditions. It is potentially widely available, but its harnessing is easiest in regions where the geothermal gradient is higher than average. This applies to several regions of Europe, especially Iceland and parts of Italy, Greece and Turkey (Hurter, S. and Haenel, R. 2003). Most countries either have quite limited production, and then almost entirely through direct use or none at all.

Geothermal resources are used either to provide thermal energy directly or to produce electricity. In Europe, the former type of usage is most important in Turkey and Iceland. In Turkey, almost a third of geothermal direct use relates to balneology-therapy and spas, with district heating and greenhouses coming next (PARLAKTUNA, M. et al. 2013). In Iceland, almost three-fourths of direct use is for district heating, $\sim 90$ per cent of such heating in the country is now geothermal (National Energy Authority 2019).

Within Europe, most geothermal electricity by far is produced in Iceland and Italy, followed by Turkey. In 2016 Turkey and Italy had the largest installed capacity (see Table 1). In Iceland, some 30 per cent of all electricity is now coming from geothermal plants (National Energy Authority 2019). Installed capacity in Island in 2016 was $665 \mathrm{MW}_{\mathrm{e}}$ (see Table 1). Two stations are found in the west of Turkey with a total of $397 \mathrm{MW}_{\mathrm{e}}$ capacity (BERTANI, R. 2015). In Germany, Portugal, France and Austria electricity production from geothermal resources is still minuscule.

Geothermal landscape is based on the use of geothermal energy (abbr. GE) for heat/ power generation. Geothermal resources are classified as either low or high enthalpy, with a temperature of $150{ }^{\circ} \mathrm{C}$, at surface pressure frequently used as the limit (MARTínGамвон, M. et al. 2015). Water from low-enthalpy geothermal fields is often suitable for direct use. Geothermal fluids from high-enthalpy fields are much more suitable for electricity production.

Whether GE is in fact 'renewable' can be debated (BARBIER, E. 2002). In low-enthalpy systems that only use naturally flowing hot water, the renewability is unquestionable. 
However, if the extraction of fluids from a particular reservoir is higher than the capacity of that reservoir to regenerate, the operation is more akin to mining a non-renewable resource (ARNóRsson, S. 2011).

Geothermal infrastructure can have a considerable impact on landscapes (KRISTMANNSDótTiR, H. and Ármannsson, H. 2003). According to van ZaLK, J. and Behrens, P. (2018) the power density of GE systems varies from 0.08 to $14.94 \mathrm{~W}_{\mathrm{e}} / \mathrm{m}^{2}$, with substantial difference between high-temperature plants $\left(\mu=4,9 \pm 2.9 \mathrm{~W} / \mathrm{m}^{2}\right)$, and low-temperature systems $\left(\mu=1.6 \pm 1.0 \mathrm{~W}_{\mathrm{e}} / \mathrm{m}^{2}\right)$. The direct footprint also varies from 2.14 to $10.96 \mathrm{~km}^{2} / \mathrm{TWhr}$ (Trainor, A.M. et al. 2016).

Negative visual landscape and environmental impacts of geothermal energy facilities are the most controversial, while land use impacts are less discussed in the reviewed literature.

In case of direct-use installations, the impact is mostly limited to wellheads and pipelines, but sometimes natural geothermal surface features may be affected. At high-enthalpy fields (used for electricity production), the landscape impact is more conspicuous and wide-ranging. Some of it occurs already at the research stage, as wells/boreholes need to be drilled. Each well pad is from 2,000 to 5,000 $\mathrm{m}^{2}$ large, and needs an access road. Some of the research wells become production wells, whereas others turn out to be unsuitable for production, yet leave the landscape altered. Following initial research, more production wells are added, as well as reinjection wells related to the other end of the production process. The linear form of gathering pipelines can be very conspicuous in the landscape, and zigzagged or U-shaped thermal expansion loops further accentuate the contrast with natural forms. Finally, the power station itself is a complex amalgam of steam separators, turbines and generators, cooling towers and other necessary facilities (Di Pippo, R. 2015). All this considered, geothermal electricity generation usually creates a very 'industrial' landscape (Photo 2).

GE is often presented to the public as almost without any substantial environmental impacts, apart from direct modifications of the physical landscape with construction. However, its landscape impacts related to environmental issues are considerable too (KRISTMANNSDÓTTIR, H. and Ármannsson, H. 2003). Especially the use of high-enthalpy fields entails a range of negative consequences, some of which can affect landscape quality in a less direct way. Stability of hillsides can be weakened by thermal changes in the soil and landslides have oc-

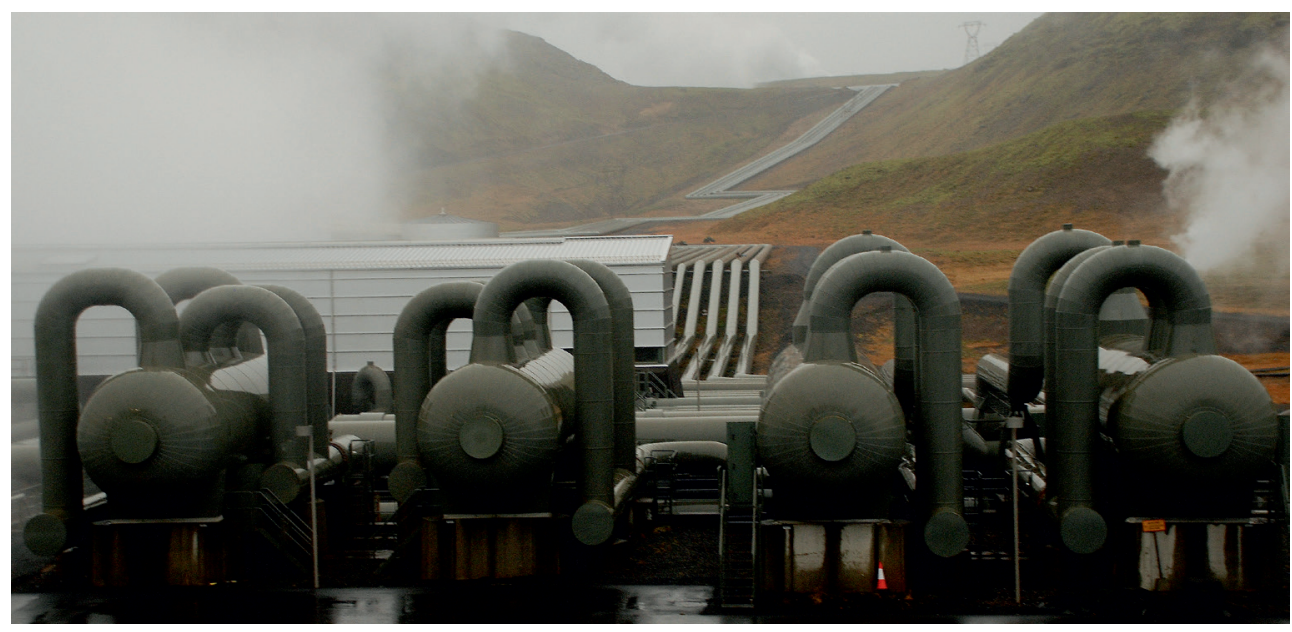

Photo 2. Hellisheiði Geothermal Power Station, Iceland (Photo by CenterI, Cs.) 
casionally followed the building of geothermal plants. Land subsidence can also occur with the extraction of fluids. Surface manifestations of geothermal activity, such as springs and fumaroles, can be altered or may disappear.

Landscape-wise, chemical pollution may alter vegetation in the vicinity of the power plant unless measures are taken to get rid of the pollutants, with e.g. reinjection of fluids. Noise from blowing boreholes and geothermal plants, and the distinctive smell of hydrogen sulfide can negatively affect the perception of landscape quality.

Geothermal fields are often located in rare or visually interesting landscapes due to peculiar surface formations (hot springs, fumaroles or craters). Due caution is therefore necessary when planning for GE infrastructure in the landscape. Careful attention to design and engineering can mitigate some of the unavoidable long-term negative impact.

Given the characteristics outlined above, it is hard to envisage positive landscape changes with GE development. The technology is rather new and has not become valued as 'industrial heritage'. In some cases, however, unforeseen landscape impacts have turned out to be positive. The best example perhaps is the 'Blue Lagoon' in Iceland, which has become a major tourist attraction and spa.

\section{Bioenergy landscapes}

Bioenergy is by far the most important category of RE in Europe, with more than 50 per cent of the total RE. Compared to other RE sources it is rather equally distributed between different countries, although it comes in many forms (solid, liquid and gaseous biofuels, sometimes with in-situ conversion to electricity). The share of bioenergy of all REs is highest in the Baltic States, the Czech Republic and Hungary. In absolute terms, Germany is by far the largest producer, followed by France, Italy and Sweden. Norwegian production is very limited, and at the other end of the spectrum are Iceland, Switzerland and Bosnia and Herzegovina, where bioenergy is almost absent (Eurostat 2016).
The growth of production and use of bioenergy was spectacular in the last decade. The leading producers since 1970s have been Brazil and the United States, but recently several European countries have become important producers like Germany, Italy, France, the Benelux countries, Spain, etc. (Solomon, B.D. and BARNETT, J.B. 2017). There are two main types of bioenergy: biofuel and biomass.

Biofuel technologies are classified into firstgeneration, where the raw material is grains or sugar beet derivatives, and advanced or second-generation technologies, where use is made of non-fossil, non-food materials. Production of the first generation technologies is limited in Europe due to lack of available land, while the biodiesel markets and feedstock production are larger (Solomon, B.D. and BARNETT, J.B. 2017). The leaders of the bioethanol production in EU are France, Germany and Belgium, while the top three producers of biodiesel/hydrogenated vegetable oils (abbr. HVO) are Germany, France and the Netherlands (FLACH, B. et al. 2016). As for advanced or second-generation biofuels its production has taken off in the EU only since the past six years, due to favourable policies for its development related to their lower greenhouse gas emissions. Several HVO thermochemical and biochemical plants have been built in Finland, the Netherlands, Spain and Italy.

The term biomass refers to various types of biological material which can be converted into energy, a solid or liquid biofuel or other products (CALvert, K. et al. 2017, 2019). There are basically three types of biomass materials. According to their origin they are classified as: (1) energy crops grown primarily for the production of energy; (2) agricultural/forest residues that are generated when grains are harvested, trees pruned/cut; (3) by-products and organic waste that is generated in the processing of biomass for the development of food products, from which energy can be recovered. Heat and power are generated either through direct combustion of biomass or through use of biomass for the biogas production. Forestry products are the main feedstock for direct combustion, while a wide range of 
inputs is used for the production of biogas. Main three pellet producers among the COST action countries are Germany, Sweden and Latvia (FLACH, B. et al. 2016). As for biogas, Germany with its 8,928 biogas plants of total capacity of 4,177 MW is the leader in biogas production, accounting for 65 per cent of total EU production. It is followed by Italy $(2,100$ plants/900 MW) (FLACH, B. et al. 2016).

The advantages of using bioenergy are accompanied, in general, by inherently problematic properties (stationarity, low-energy density, scattering, direct and indirect land-use change, etc.) (GARcía-Frapolli, E. et al. 2010).

Land-use and environmental impacts are the main concerns of the literature on bioenergy, while visual impacts are less discussed in the reviewed literature. Bioenergy induces direct and indirect land-use changes, the latter when pre-existing agricultural activity is converted into new, often more intensified forms of agriculture (PALmer, J.R. 2014). Bioenergy transforms pre-existing agricultural landscapes and their related social practices, thereby imposing new value system on landscape (CALvert, $K$. et al. 2017). Biomass systems have very low median power density of $0.08 \mathrm{~W}_{\mathrm{e}} / \mathrm{m}^{2}(\mu=0.13$ $\left.\pm 0.02 \mathrm{~W} / \mathrm{m}^{2}\right)$, and low maximum power density $\left(0.60 \mathrm{~W} / \mathrm{m}^{2}\right)$ (VAN ZALK, J. and BeHRENS, P. 2019). Therefore, large amounts of biomass must be grown that leads to re-surfacing of infrastructure and activity associated with biomass distribution and conversion.

Bioenergy surface area requirements are the highest among the RE technologies, with the average area of direct footprint estimated as $809.74 \mathrm{~km}^{2} / \mathrm{TWhr}$ (557.93 to $1,254.03 \mathrm{~km}^{2} /$ TWhr) (TrainOR, A.M. et al. 2016). In addition, biogas tends to be produced on a large industrial scale, which in some cases leads to important impacts on landscape character and its decoupling from the local community (Bluemling, B. et al. 2013).

Due to diversity of subtypes and scales of bioenergy landscapes they may belong both to 'component' type and 'entity energy landscape'. The biomass processing facilities could vary in size (CALvert, K. et al. 2017), so their landscape impact is scale-dependent.
Bioenergy indirect landscape impacts related to environmental issues are multiple: effect on soil, gaseous emissions, unfamiliar smell and possibility of water pollution (НАsтıк, R. et al. 2015; SoKKA, L. et al. 2016). The continued withdrawal of organic matter from the forest may have very negative impacts on landscape due to decrease of soil quality and mediumterm impacts on the landscape (Holland, R.A. et al. 2015). There may be long time-lags before the populations reach new equilibriums after the extraction of bioenergy is initiated (Johansson, V. et al. 2016).

In order to minimize some negative consequences of bioenergy production on landscape the production of energy crops is often encouraged or restricted onto land considered marginal or abandoned for agricultural purposes (CAlvert, K. et al. 2017). Another more general strategy in bioenergy policy is to favour development of advanced or second generation of biofuels that use a wider range of feedstock including lingo-cellulosic material, waste and residues or stimulate production of algae origin biodiesel and do not compete with food production. For landscape management and protection, the policies regulating the development of bioenergy should be integrated into agricultural, forest and environmental protection policies.

The production of second-generation biofuels from the valorisation of domestic and forest waste is a route with very positive impacts in terms of landscape and environmental value. The recovery of waste allows them to be valued, reducing the negative impacts of dumps and landfills. The use of forest residues makes it possible to prevent forest fires, which are particularly significant in the countries of southern Europe and which have drastic consequences in terms of landscape and environment.

Finally, positive experiences of eco-remediation of degraded land by growing energy crops (FrAntáL, B. 2018) and visualization of bioenergy landscapes through using them as a part of nature trail or incorporating bioenergy facilities into historical farm buildings (FrANTÁL, B. 2018) make us suggest that bioenergy landscapes may offer good examples of sustainable energy landscapes. 


\section{Infrastructure energy landscapes}

RE installations entail an ensemble of auxiliary elements referred to assimilation, conversion, storage, transport or transmission of energy produced. Although they may differ greatly across the different energy sources, in general terms infrastructure energy landscapes include ancillary buildings, substations and transmission lines, roads, tracks, canals and access tracks. They can have as much impact on the landscape quality, or more, than the very devices which produce power from renewable sources (SwANwick, C. 2002; Uyterlinde, M. et al. 2017). Associated hazards and needed accessibility, both directly and indirectly, discourage other land uses along these infrastructures, sometimes creating and dividing function between land uses on either side of their pathway (PAsQUALETTI, M. and STREMKe, S. 2018).

In addition, the auxiliary elements may have impacts on the materiality of historical and natural heritage, mainly when they interfere with archaeological sites or historical areas or require deforestation of buffer zone (Harvey, A. and Moloney, K. 2013). These elements may also cause perceptual alterations or modification of the visual relations of scale and hierarchy between the different elements that compose a scene (Landscape Institute and Institute of Environment Management and Assessment 2013).

Finally, new roads and access tracks for the maintenance of facilities produce an increased accessibility in areas that often were previously difficult to access or inaccessible, in detriment of their wilderness (Scottish Natural Heritage 2003).

\section{Discussion and conclusions}

Today, renewable energy landscapes are part of European landscapes. Due to differences in components, spatial extent and visual dominance of different RE facilities, there is a considerable variety of sub-types of RE landscapes.
The overview of the state of RE developments shows a great diversity and an uneven distribution of RE landscapes in Europe. Italy and Turkey are the countries with the most varied RE landscapes with a significant presence of most RE types, while Bosnia and Herzegovina have the most uniform RE landscape with an absolute predominance of hydropower.

Most RE landscapes can be classified both as 'component' and 'layer' types or as 'entity energy landscape' (Table 2). According to the consulted literature, visual landscape impact is the most important concern for wind, BAPV/BIPV and BA/BI hot water and space heating, CSP and small-scale geothermal energy landscape. Land use impacts is the most cited impacts group for on-ground solar PV, bio- and infrastructure energy landscapes; and landscape impacts related to environmental issues, in particular to biodiversity and water issues, for large-scale hydro and high temperature geothermal energies.

In spite of these differences, all the consulted authors consider visual/aesthetic landscape impacts of REs as an important issue. The impact also depends on the landscape type concerned, and may be relatively higher in rural areas with open or exposed views. Associated infrastructures may also have a significant impact and often form a different 'infrastructure energy landscape'. Due to unique visual properties of the most part of RE facilities combined with large size, ordered angular geometry, and highly reflective surfaces of wind and solar power plants, they add strongly contrasting artificial elements to the landscape. Landscape impacts of all the RE developments depend on their sub-type, size and the landscape in which they are placed. However, generally the question of the RE project's scale is crucial. Although the small-scale projects generally have a smaller landscape impact, the cumulative impact of multiple small-scale projects could exceed that of one large-scale project (BAKKEN, T.H. 2014; Scottish Natural Heritage, 2014). 


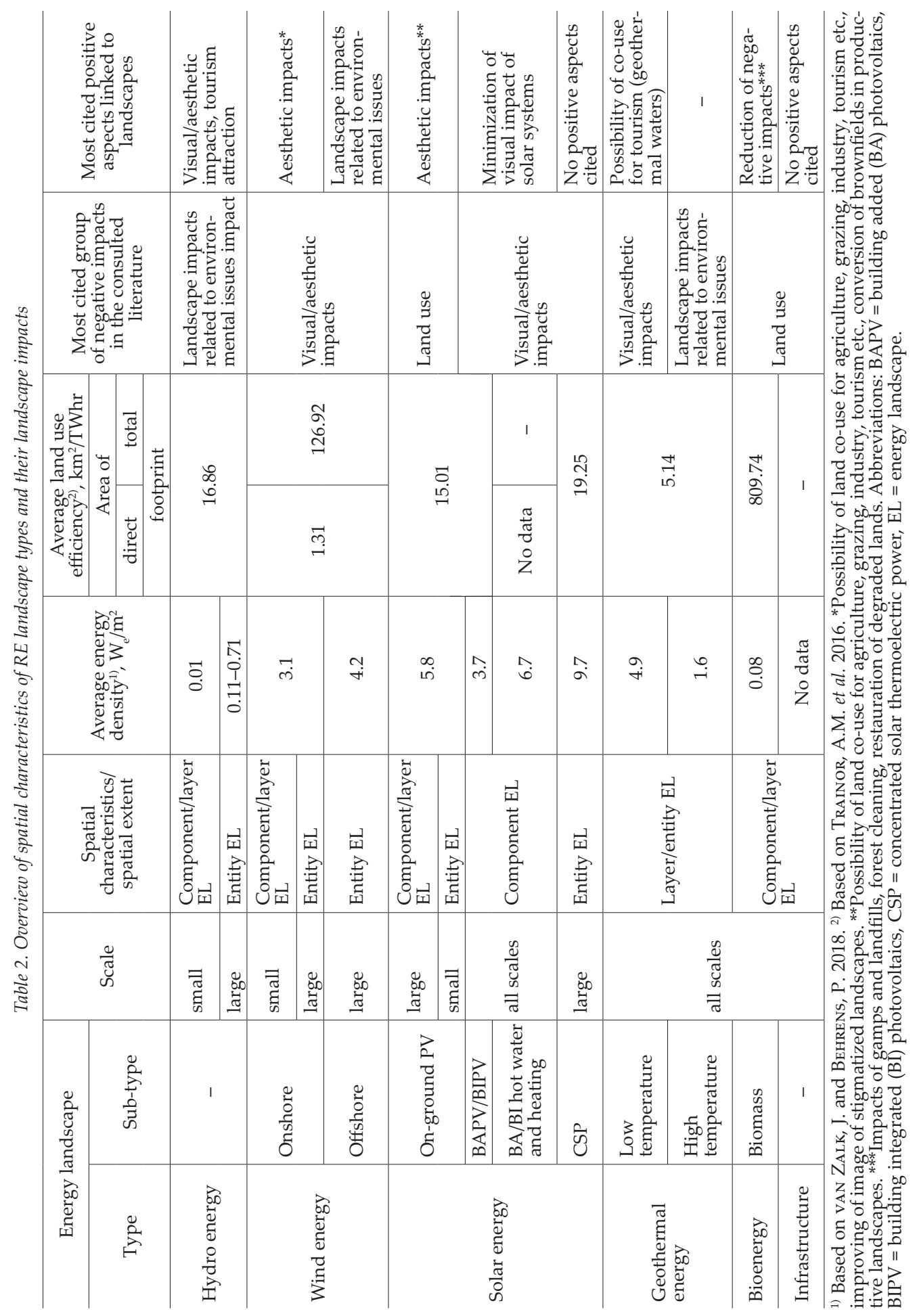


The extensive nature of land occupation of RE systems that affects landscape quality is a widely discussed topic too. These facilities do not merely represent new elements in the landscape, but often change the patterns of the landscapes concerned. Adverse, permanent effects of RE systems on landscape, arising at a larger scale, are of greater concern in the literature on RE impacts.

Direct land occupation of RE facilities raises the issue of the spatial extent of lowdensity renewable technologies with a large land use footprint, termed 'energy sprawl' (Trainor, A.M. et al. 2016). Renewable power density means varies greatly from 0.08 for biomass to $6.6 \mathrm{~W}_{\mathrm{e}} / \mathrm{m}^{2}$ for solar (VAN ZALK, J. and Behrens, P. 2019). There is a considerable difference between power densities of different sub-types of renewables, depending on their characteristics and scale (see Table 2).

As for land use efficiency, it does not always directly depend on power density. It varies substantially too, from $1.31 \mathrm{~km}^{2} / \mathrm{TWhr}$ for wind energy to $809 \mathrm{~km}^{2} / \mathrm{TWhr}$ for biomass. However, when indirect landscape impact is considered, wind is estimated as one of the least land-use efficient sources of electricity, due to the total area occupied by wind farms and their infrastructures (TrAINOR, A.M. et al. 2016; van ZALK, J. and Behrens, P. 2019) (see Table 2). Interestingly, according to the estimations of Trainor, A.M. et al. (2016), despite CSP having the highest value of power density among RE systems, its average land use efficiency estimation is lower and the area of direct footprint is higher than the average values for geothermal, solar PV and hydro energy systems (see Table 2).

The comparison of land occupation and the share of different RE types in total RE production in Europe (see Figure 1), can help to identify some critical landscape issues that need further study. Bioenergy landscape is the most important category of RE landscape in Europe, not only due to the bioenergy share in the total RE mix and its presence in many European countries, but also owing to its great land use footprint. The next in importance is the wind energy landscape. In spite of its share in the RE mix being much lower than that of hydro energy, the second most important source in Europe, its total footprint is over 7.5 times more extensive. Geothermal energy and CSP landscapes are the less extended in Europe.

In addition, RE systems often involve greenfield development, limiting the opportunities for food production in agriculture (Azar, C. 2005; Rathmann, R. et al. 2010) or for tourism (SÆьórsDótTIR, A.D. and Ólafsson, R. 2010).

Landscapes that have been dominated by extensive technical installations help to assimilate RE developments due to thematic association with industrial structures (Danish Energy Agency 2009). Appropriate design can further reduce visual misfit of RE facilities. Generally small-scale deployments are considered a way to reduce landscape impacts of most RE infrastructures, however, having limited and insufficient outputs to achieve long-term national targets for emission reduction (FRANTÁL, B. 2018) and creating cumulative impact of multiple RE plants.

Strategic planning and landscape character studies are important tools to mitigate potential adverse landscape and accumulative effects with proper siting. Landscape Character Assessments provide a good basis for both location and design of RE developments.

The review has revealed several gaps related to the studies of impact of RE facilities that should be brought into the focus of scientific research. Most publications center on the facilities necessary for energy production, while other structures associated with RE systems get less attention. However, they should also be located and designed with respect to the character of surrounding landscapes. Increased research activity in these fields would result in a better understanding and management of this complex issue.

Bioenergy landscapes should receive much more attention in the future European research, due to their spatial extent and the important role of bioenergy in the RE mix of many countries. On the other hand, despite constantly growing energy density of 
wind energy facilities, their landscape effects should continue to be considered an important concern, due to their considerable presence in Europe and extensive area of indirect footprint. The considerable spatial extent of hydro energy facilities, both due to their significant role in the energy mix of many European countries and large direct footprint, should be taken into consideration in the future studies of their landscape impacts.

Finally, the review shows that perception of different RE landscapes depends not only on technical and visual characteristics of RE facilities, but also on the landscape in which they are placed. In addition, aesthetical assimilation of RE systems depends on historical and socio-cultural background of its development, on relation between local people and their resources and possibilities to use $\mathrm{RE}$ landscape for other territorial practices.

As numerous studies argue, landscapes may benefit both from the socio-economic impacts of RE developments and from 'smart practices' developed within RE landscapes. Therefore, we can suggest that if RE projects are properly located and designed and are beneficial for local people and tourists, society will gradually learn to love these landscapes and to adapt to their aesthetic properties.

Acknowledgements: This paper was elaborated in the scope of the research of the Working Group One of the COST Action TU1401 RELY (Renewable Energy and Landscape Quality), supported by the EU Framework Program Horizon 2020. The data were updated with the research carried out within the project ADAPTAS (Ministry of Economy, Industry and Competitiveness and State Research Agency of Spain, and European Regional Development Fund, CSO2017-86975-R).

\section{REFERENCES}

Abbasi, T. and Abbasi, S.A. 2011. Small hydro and the environmental implications of its extensive utilization. Renewable and Sustainable Energy Reviews 15. (4): 2134-2143.

Andrés-Ruiz (de), C., Iranzo-García, E. and EspejoMARín, C. 2015. Solar thermoelectric power landscapes in Spain. In Renewable Energies and European Landscapes. Lessons from Southern European Cases. Eds.:
Frolova, M., Prados, M. and Nadaï, A., Dordrecht, Springer, 237-254.

Arnórsson, S. 2011. Jarðhiti á Íslandi: Eðli auðlindar og ending - Verklag við undirbúning að vinnslu Umhverfisáhrif af nýtingu. Reykjavík, Rammaáætlun.

Azar, C. 2005. Emerging scarcities - bioenergy-food competition in a carbon constrained world. In Scarcity and growth revisited: natural resources and the environment in the new millennium. Eds.: Simpson, R.D., Toman, M.A. and Ayres, R.U., Washington D. C., Resources for the Future, 98-120.

Bakken, T.H., Aase, A.G., Hagen, D., Sundt, H., Barton, D.N. and Lujala, P. 2014. Demonstrating a new framework for the comparison of environmental impacts from small- and large-scale hydropower and wind power projects. Journal of Environmental Management 140. 93-101.

BARBIER, E. 2002. Geothermal energy technology and current status: an overview. Renewable and Sustainable Energy Reviews 6. (1-2): 3-65.

BELL, S. 2017. Adjusting to renewable energy in a crowded Europe. In The Renewable Energy Landscape Preserving Scenic Values in our Sustainable Future. Eds.: Apostol, D., Palmer, J., Pasqualetti, M., Smardon, R. and Sullivan, R., London-New York, Routledge, 78-187.

Benediktsson, K., Frolova, M., Centeri, Cs. and HeNNIG, B. 2018. Introduction: Energy landscape and landscape quality. In Renewable Energy and Landscape Quality. Eds.: Roth, M., Eiter, S., RöHner, S., Kruse, A., Schmitz, S., Frantál, B., Centeri, Cs., Frolova, M., Buchecker, M., Stober, D., Karan, I. and vaN DER HORST, D., Berlin, JOVIS Verlag GmbH., 104-123. https://www.jovis.de/en/books/details/product/ renewable-energy-and-landscape-quality.html

Bergström, L., Kautsky, L., Malm, T., Rosenberg, R., Wahlberg, M., Åstrand Capetillo, N. and Wilhelmsson, D. 2014. Effects of offshore wind farms on marine wildlife - A generalized impact assessment. Environmental Research Letters 9. (3): 1-12.

BERTANI, R. 2015. Geothermal power generation in the world 2010-2014. Update Report. In Proceedings World Geothermal Congress 2015. Melbourne 19-25 April 2015. https://www.geothermal-energy.org/ pdf/IGAstandard/WGC/2015/01001.pdf

BevK, T. and Golobič, M. 2018. What fits where? Landscape approach to renewable energy development. In Renewable Energy and Landscape Quality. Eds.: Roth, M., Eiter, S., Röhner, S., Kruse, A., Schmitz, S., Frantál, B., Centeri, Cs., Frolova, M., Buchecker, M., Stober, D., Karan, I. and van DeR Horst, D., Berlin, JOVIS Verlag GmbH., 139-144.

Bilgili, M., YASAR, A. and SimseK, E. 2011. Offshore wind power development in Europe and its comparison with onshore counterpart. Renewable and Sustainable Energy Reviews 15. (2): 905-915.

Bishop, I.D. and Miller, D.R. 2007. Visual assessment of off-shore wind turbines: The influence of 
distance, contrast, movement and social variables. Renewable Energy 32. (5): 814-831.

Bluemling, B., Mol, A.P.J. and Tu, Q. 2013. The social organization of agricultural biogas production and use. Energy Policy 63. 10-17.

ČADA, G.F. 2001. The development of advanced hydroelectric turbines to improve fish passage survival. Fisheries 26. (9): 14-23.

Calvert, K., Birch, K. and Mabee, W. 2017. New perspectives on an ancient energy resource: Biomass, bioenergy, andemerging bio-economies. In The Routledge Research Companion to Energy Geographies. Eds.: Bouzarovski, S., Pasqualetti, M.J. and Castan Ввото, V., Routledge, Abingdon-New York, 47-60.

Calvert, K., Greer, K. and Maddison-MacFadyen, M. 2019. Theorizing energy landscapes for energy transition management: Insight from a socioecological history of energy transition in Bermuda. Geoforum 102. 191-201.

Chiabrando, R., Fabrizio, E. and Garnero, G. 2009. The territorial and landscape impacts of photovoltaic systems: Definition of impacts and assessment of the glare risk. Renewable and Sustainable Energy Reviews 13. (9): 2441-2451.

Cohen, J.J., Reichl, J. and Schmidthaler, M. 2014. Re-focussing research efforts on the public acceptance of energy infrastructure: A critical review. Energy 76. 4-9.

Cushman, R.M. 1985. Review of ecological effects of rapidly varying flows downstream from hydroelectric facilities. North American Journal of Fisheries Management 5. (3A): 330-339.

Danish Energy Agency 2009. Wind turbines in Denmark. www.ens.dk

Department of the Environmental, Heritage and Local Government, Ireland 2006. Wind Energy Development Guidelines. www.environ.ie

Devine-Wright, P. and Batel, S. 2017. My neighbourhood, my country or my planet? The influence of multiple place attachments and climate change concern on social acceptance of energy infrastructure. Global Environmental Change 47. 110-120.

Di Pippo, R. 2015. Geothermal power plants: Evolution and performance assessments. Geothermics 53. 291-307.

Dijkman, T.J. and Benders, R.M.J. 2010. Comparison of renewable fuels based on their land use using energy densities. Renewable and Sustainable Energy Reviews 14. (9): 3148-3155.

ESTIF 2015. Solar Thermal Markets in Europe. Trends and Market Statistics 2015. http://www.estif.org/ fileadmin/estif/content/publications/downloads/ Online_version_-_Solar_Thermal_Markets_in_ Europe_-_Summary_-_Final_version.pdf

EurObserv'ER 2017. Solar thermal and concentrated solar power barometer 2017. https://www.eurobserv-er. org/solar-thermal-and-concentrated-solar-powerbarometer-2017-3/
European Commission 2009. Directive 2009/28/EC of the European Parliament and of the Council, on the promotion of the use of energy from renewable sources and amending and subsequently repealing Directives 2001/77/EC and 2003/30/EC. Brussels: Official Journal of the European Union L140/16.

European Commission 2013. Hydropower. https:// setis.ec.europa.eu/system/files/Technology_ Information_Sheet_Hydropower.pdf

European Commission 2015. Hydropower. https:// setis.ec.europa.eu/system/files/Technology Information_Sheet_Hydropower.pdf

Eurostat 2016. Energy from renewable sources. http:// ec.europa.eu/eurostat/statistics-explained/index. php/Energy_from_renewable_sources

Evans, A., Strezov, V. and Evans, T.J. 2009. Assessment of sustainability indicators for renewable energy technologies. Renewable and Sustainable Energy Reviews 13. (5): 1082-1088.

Fernandez-Jimenez, L.A., Mendoza-Villena, M., Zorzano-Santamaria, P., Garcia-Garrido, E., Lara-Santillan, P., Zorzano-Alba, E. and Falces, A. 2015. Site selection for new PV power plants based on their observability. Renewable Energy 78. 7-15.

Flach, B., Lieberz, S., Rondon, M., Williams, B. and Wilson, C. 2016. EU-28 Biofuels Annual 2016. Global Agricultural Information Network, Report Num. 42. (June 2016). USDA Foreign Agricultural Service. https://apps.fas.usda.gov/newgainapi/api/report/ downloadreportbyfilename?filename $=$ Biofuels $\% 20$ Annual_The\%20Hague_EU-28_6-29-2016.pdf

FrantáL, B. 2018. Energy tourism: Embracing the visibility of renewables as an asset in the contemporary place competition. In Renewable Energy and Landscape Quality. Eds.: Roth, M., EITER, S., RöHNeR, S., Kruse, A., Schmitz, S., Frantál, B., Centeri, Cs., Frolova, M., Buchecker, M., Stober, D., Karan, I. and VAN DeR Horst, D., Berlin, JOVIS Verlag GmbH., 164-165.

Frantál, B., van der Horst, D., Martinát, S., Schmitz, S., Teschner, N., Silva, L., Golobic, M. and Rотн, M. 2018. Spatial targeting, synergies and scale: Exploring the criteria of smart practices for siting renewable energy projects. Energy Policy 120. 85-93.

Frolova, M. 2010. Landscapes, water policy and the evolution of discourses on hydropower in Spain. Landscape Research 35. (2): 235-257.

Frolova, M. 2017. Construction of hydropower landscapes through local discourses. In The Routledge Research Companion to Energy Geographies. Eds.: Bouzarovski, S., Pasqualetti, M.J. and Castan Ввото, V., Abingdon-New York, Routledge, 217-233.

Frolova, M., Prados, M. and Nadaï, A. 2015a. Emerging renewable energy landscapes in Southern European countries. In Renewable Energies and 
European Landscapes. Lessons from Southern European Cases. Eds.: Frolova, M. Prados, M. and Nadaї, A., Dordrecht, Springer, 3-24.

Frolova, M., Prados, M. and Nadaï, A. (eds.) 2015 b. Renewable Energies and European Landscapes: Lessons from Southern European cases. Dordrecht, Springer. www.springer.com/us/book/9789401798426

Frolova, M., Jiménez-Olivencia, Y., Sánchez-del Árbol, M., Requena-Galipienso, A. and PérezPérez, B. 2015c. The evolution of renewable landscapes in Sierra Nevada (Southern Spain). From small hydro- to a wind-power landscape. In Renewable Energies and European Landscapes: Lessons from Southern European cases. Eds.: Frolova, M., Prados, M. and Nadaï, A. Dordrecht, Springer, 117-134.

Fthenakis, V. and Kim, H.C. 2009. Land use and electricity generation: A life-cycle analysis. Renewable and Sustainable Energy Reviews 13. 1465-1474.

García-Frapolli, E., Schilmann, A., Berrueta, V.M., Riojas-Rodríguez, H., Edwards, R.D., Johnson, M., Guevara-Sanginés, A., Armendariz, C. and Masera, O. 2010. Beyond fuelwood savings: Valuing the economic benefits of introducing improved biomass cookstoves in the Purépecha region of Mexico. Ecological Economics 69. (12): 2598-2605.

Harvey, A. and Moloney, K. 2013. The onshore wind farm sector in Ireland: Planning in harmony with heritage. Policy Research Paper, Volume 1 and 2. The Heritage Council. http://oldsitehc.info/fileadmin/ user_upload/Planning/2013/windfarm_Overview. pdf

Hastik, R., Basso, S., Geitner, C., Haida, C., Poljanec, A., Portaccio, A., Vrščaj, B. and Walzer, C. 2015. Renewable energies and ecosystem service impacts. Renewable and Sustainable Energy Reviews 48. 608-623.

Henderson, A.R., Morgan, C., Smith, B., Sørensen, H.C., Barthelmie, R.J. and Boesmans, B. 2003. Offshore wind energy in europe - A review of the state-of-the-art. Wind Energy 6. (1): 35-52.

Hernandez, R.R., Easter, S.B., Murphy-Mariscal, M.L., Maestre, F.T., Tavassoli, M., Allen, E.B., Barrows, C.W., Belnap, J., Ochoa-Hueso, R., Ravi, S. and Allen, M.F. 2014. Environmental impacts of utility-scale solar energy. Renewable and Sustainable Energy Reviews 29. 766-779.

Holland, R.A., Eigenbrod, F., Muggeridge, A., Brown, G., Clarke, D. and Taylor, G. 2015. A synthesis of the ecosystem services impact of second generation bioenergy crop production. Renewable and Sustainable Energy Reviews 46. 30-40.

Horner, R.M. and Clark, C.E. 2013. Characterizing variability and reducing uncertainty in estimates of solar land use energy intensity. Renewable and Sustainable Energy Reviews 23. 129-137.

Hurtado, J.P., Fernández, J., Parrondo, J.L. and Blanco, E. 2004. Spanish method of visual impact evaluation in wind farms. Renewable and Sustainable Energy Reviews 8. (5): 483-491.

Hurter, S. and Haenel, R. 2003. Atlas of geothermal resources in Europe. Geothermics 32. (4-6): 779-787.

Inger, R., Attrill, M.J., Bearhop, S., Broderick, A.C., James Grecian, W., Hodgson, D.J., Mills, C., Sheehan, E., Votier, S.C. and Witt, M.J. 2009. Marine renewable energy: potential benefits to biodiversity? An urgent call for research. Journal of Applied Ecology 46. (6): 1145-1153.

Johansson, V., Felton, A. and Ranius, T. 2016. Longterm landscape scale effects of bioenergy extraction on dead wood-dependent species. Forest Ecology and Management 371. 103-113.

Kapetanakis, I.A., Kolokotsa, D. and Maria, E.A. 2014. Parametric analysis and assessment of the photovoltaics' landscape integration: Technical and legal aspects. Renewable Energy 67. 207-214.

KIL, J. 2011. Environmental and spatial effects of constructing a wind power plant. 'Issues of Landscape Conservation and Water Management in Rural Areas'. Contemporary Problems of Management and Environmental Protection 7. 63-76.

Kontogianni, A., Tourkolias, C. and Skourtos, M. 2013. Renewables portfolio, individual preferences and social values towards RES technologies. Energy Policy 55. 467-476.

Koutsoyiannis, D. 2011. Scale of water resources development and sustainability: small is beautiful, large is great. Hydrological Sciences Journal 56. (4): 553-575.

Kristmannsdóttir, H. and Ármannsson, H. 2003. Environmental aspects of geothermal energy utilization. Geothermics 32. (4-6): 451-461.

LADENBURG, J. 2009. Visual impact assessment of offshore wind farms and prior experience. Applied Energy 86 (3): 380-387.

Lakhani, R., Doluweera, G. and Bergerson, J. 2014. Internalizing land use impacts for life cycle cost analysis of energy systems: A case of California's photovoltaic implementation. Applied Energy 116. 253-259.

Landscape Institute and Institute of Environment Management and Assessment 2013. Guidelines for Landscape and Visual Impact Assessment. $3^{\text {rd }}$ edition. Abington, Taylor and Francis.

Lindeboom, H.J., Kouwenhoven, H.J., Bergman, M.J.N., Bouma, S., Brasseur, S., DaAn, R., Fijn, R.C., De HaAn, D., DiRKSEN, S. and van HAL, R. 2011. Short-term ecological effects of an offshore wind farm in the Dutch coastal zone; a compilation. Environmental Research Letters 6. (3): 035101.

Linnane, A., Mazzoni, D. and Mercer, J.P. 2000. A longterm mesocosm study on the settlement and survival of juvenile European lobster Homarus gammarus L. in four natural substrata. Journal of Experimental Marine Biology and Ecology 249. (1): 51-64.

Martín-Gamboa, M., Iribarren, D. and Dufour, J. 2015. On the environmental suitability of high-and low-enthalpy geothermal systems. Geothermics 53. 27-37. 
Mauthner, F., Weiss, W. and Spörk-Dür, M. 2016. Solar heat worldwide. Markets and Contribution to the Energy Supply 2014. Solar Heating and Cooling Programme. International Energy Agency. https:// www.iea-shc.org/data/sites/1/publications/SolarHeat-Worldwide-2015.pdf

MEDDE 2010. Guide de l'étude d'impact sur l'environnement des parcs éoliens (actualisation 2010), Ministère de l'Écologie, de l'Énergie, du Développement durable et de la Mer, en charge des Technologies vertes et des Négociations sur le climat. www.ecologique-solidaire. gouv.fr/sites/default/files/guide_eolien_15072010.pdf

Minelli, A., Marchesini, I., Taylor, F.E., De Rosa, P., Casagrande, L. and Cenci, M. 2014. An open source GIS tool to quantify the visual impact of wind turbines and photovoltaic panels. Environmental Impact Assessment Review 49. 70-78.

MöLler, B. 2010. Spatial analyses of emerging and fading wind energy landscapes in Denmark. Land Use Policy 27. (2): 233-241.

National Energy Authority 2019. Energy Statistics in Iceland 2014. http://os.is/gogn/os-onnur-rit/orkutolur_2014-enska.pdf

Nordmann, T., Ossenbrink, H. and Vontobel, T. 2010. Large scale PV implementation and grid integration with hybrid PV hydro power plants using floating PV devices-potential study and future markets. In $25^{\text {th }}$ EUPVSEC Proceedings. 6-10 September 2010. Valencia, Spain, EUPVSEC, 5231-5234.

OLwIG, K.R. 2007. The practice of landscape 'Conventions' and the just landscape: The case of the European landscape convention. Landscape Research 32. (5): 579-594.

Palmer, J.R. 2014. Biofuels and the politics of land-use change: tracing the interactions of discourse and place in European policy making. Environment and Planning A 46. (2): 337-352.

Parlaktuna, M., Mertoglu, O., Simsek, S., Paksoy, H. and BASARIR, N. 2013. Geothermal country update report of Turkey (2010-2013). In Proceedings of European geothermal congress. https://www.geothermal-energy. org/pdf/IGAstandard/EGC/2013/EGC2013_CUR-32. pdf

Pasqualetti, M. and Smardon, R. 2017. Conserving scenery during an energy transition. In The Routledge Research Companion to Energy Geographies. Eds.: Bouzarovski, S., Pasqualetti, M.J. and Castan Broto, V., Abingdon-New York, Routledge, 17-40.

Pasqualetti, M. and Stremke, S. 2018. Energy landscapes in a crowded world: A first typology of origins and expressions. Energy Research $\mathcal{E}$ Social Science 36. 94-105.

Pasqualetti, M.J. 2011. Opposing wind energy landscapes: a search for common cause. Annals of the Association of American Geographers 101. (4): 907-917.

Pasqualetti, M.J. 2013. Reading the changing energy landscape. In Sustainable Energy Landscapes: Designing, Planning, and Development. Eds.: STremke, S. and van den Dobbelsteen, A., CRC Press, Baton Rouge, 11-44.
Picchi, P., van Lierop, M., Geneletti, D. and Stremke, S. 2019. Advancing the relationship between renewable energy and ecosystem services for landscape planning and design: A literature review. Ecosystem Services 35. 241-259.

Prados, M.J. 2010. Renewable energy policy and landscape management in Andalusia, Spain: The facts. Energy Policy 38. (11): 6900-6909.

Rathmann, R., Szklo, A. and Schaeffer, R. 2010. Land use competition for production of food and liquid biofuels: An analysis of the arguments in the current debate. Renewable Energy 35. (1): 14-22.

Ravi, S., Macknick, J., Lobell, D., Field, C., Ganesan, K., Jain, R., Elchinger, M. and Stoltenberg, B. 2016. Colocation opportunities for large solar infrastructures and agriculture in drylands. Applied Energy 165. 383-392.

Río, (Del), P., Peñasco, C. and Mir-Artigues, P. 2018. An overview of drivers and barriers to concentrated solar power in the European Union. Renewable and Sustainable Energy Reviews 81. 1019-1029.

Rosenberg, D.M., Bodaly, R.A. and Usher, P.J. 1995. Environmental and social impacts of large scale hydroelectric development: who is listening? Global Environmental Change 5. (2): 127-148.

Roth, M., Eiter, S., Röhner, S., Kruse, A., Schmitz, S., Frantál, B., Centeri, Cs., Frolova, M., Buchecker, M., Stober, D., Karan, I. and van der Horst, D. (eds.) 2018. Renewable Energy and Landscape Quality. Berlin, JOVIS Verlag GmbH.

RöHner, S. and Roth, M. 2018. Energy roads and roofs: Providing synergy with existing infrastructures. In Renewable Energy and Landscape Quality. Eds.: Roth, M., Eiter, S., Röhner, S., Kruse, A., Schmitz, S., Frantál, B., Centeri, Cs., Frolova, M., Buchecker, M., Stober, D., Karan, I. and van der Horst, D., BerLin, JOVIS Verlag GmbH., 156-157.

Ruggiero, F. and Scaletta, G. 2014. Environmental integration of wind farms: The territorial governance. Energy and Power Engineering 6. (11): 386-400.

SÆbórsdótTir, A.D. and Ólafsson, R. 2010. Nature tourism assessment in the Icelandic Master Plan for geothermal and hydropower development. Part II: assessing the impact of proposed power plants on tourism and recreation. Journal of Heritage Tourism 5. (4): 333-349.

SснӧвеL, S., Dittrich, A.R. and Czechowski, D. 2012. Energy landscape visualization: scientific quality and social responsibility of a powerful tool. In Sustainable Energy Landscapes: Designing, Planning, and Development. Vol. 7., Eds.: Stremke, S. and Dobbelsteen, A., Boca Raton, CRC Press, 133-160. Scognamiglio, A. 2016. "Photovoltaic landscapes": Design and assessment. A critical review for a new transdisciplinary design vision. Renewable and Sustainable Energy Reviews 55. 629-661.

Scottish Natural Heritage 2003. Wildness in Scotland's Countryside. Policy Statement No. 02/03. www. 
nature.scot/sites/default/files/2017-06/A150654 policy statement 0203 - wildness in Scotland\%27s countryside - 2003.pdf

Scottish Natural Heritage 2014. Siting and Designing wind farms in the Landscape, Version 1. Inverness, SNH. https://www.nature.scot/sites/default/files/ Publication\%202014\%20-\%20Siting\%20and\%20 designing $\% 20$ wind $\% 20$ farms $\% 20$ in $\% 20$ the $\% 20$ landscape \%20-\%20Version\%202.pdf

Sismani, G., Babarit, A. and Loukogeorgaki, E. 2017. Impact of fixed-bottom offshore wind farms on the surrounding wave field. International Journal of Offshore and Polar Engineering 27. (4): 357-365.

Sokka, L., SinkKo, T., Holma, A., Manninen, K., Pasanen, K., Rantala, M. and Leskinen, P. 2016. Environmental impacts of the national renewable energy targets - A case study from Finland. Renewable and Sustainable Energy Reviews 59. 1599-1610.

Solomon, B.D. and Barnett, J.B. 2017. The changing landscape of biofuels: A global review. In The Routledge Research Companion to Energy Geographies. Eds.: Bouzarovski, S., Pasqualetti, M.J. and Broto, V.C., London, Routledge, 61-78. https://www.routledge.com/The-Routledge-Research-Companionto-Energy-Geographies/Bouzarovski-PasqualettiBroto/p/book/9781472464194

Stevović, S., Milošević, H., Stevović, I. and Hadrović, S. 2014. Sustainable management of water resources in Prokletije region. Industrija 42. 47-61.

Strachan, P., LaL, D. and Toke, D. 2009. Wind power and power politics: international perspectives. London, Routledge.

Sullivan, R.G., Kirchler, L.B., Cothren, J. and WINTERS, S.L. 2013. Offshore wind turbine visibility and visual impact threshold distances. Environmental Practice 15. (1): 33-49.

Swanwick, C. 2002. Landscape Character Assessment. Guidance for England and Scotland. The Countryside Agency and Scottish Natural Heritage. Inverness, SNH.

ToKe, D., Breukers, S. and Wolsink, M. 2008. Wind power deployment outcomes: How can we account for the differences? Renewable and Sustainable Energy Reviews 12. (4): 1129-1147.
Tougaard, J., madsen, P.T. and Wahlberg, M. 2008. Underwater noise from construction and operation of offshore wind farms. Bioacoustics 17. (1-3): 143-146.

Trainor, A.M., McDonald, R.I. and Fargione, J. 2016. Energy sprawl is the largest driver of land use change in United States. PLoS one 11(9): e0162269.

Tsantopoulos, G., Arabatzis, G. and Tampakis, S. 2014. Public attitudes towards photovoltaic developments: Case study from Greece. Energy Policy 71. 94-106.

Turney, D. and Fthenakis, V. 2011. Environmental impacts from the installation and operation of largescale solar power plants. Renewable and Sustainable Energy Reviews 15. (6): 3261-3270.

Upreti, B.R. and van DER Horst, D. 2004. National renewable energy policy and local opposition in the UK: the failed development of a biomass electricity plant. Biomass and Bioenergy 26. (1): 61-69.

Uyterlinde, M., Londo, M., Sinke, W., van Roosmalen, J., Eecen, P., van den Brink, R., Stremke, S., van deN BRINK, A. and DE WAAL, R. 2017. Energy Transition: A new Dimension in Our Landscape. Wageningen, ECN

VAN ZALK, J. and Behrens, P. 2018. The spatial extent of renewable and non-renewable power generation: A review and meta-analysis of power densities and their application in the U.S.. Energy Policy 123. 83-91.

Wilhelmsson, D., Malm, T. and Öhman, M.C. 2006. The influence of offshore windpower on demersal fish. ICES Journal of Marine Science 63. (5): 775-784.

Wilson, J.C. and ElLiotT, M. 2009. The habitat-creation potential of offshore wind farms. Wind Energy 12. (2): 203-212.

Wolsink, M. 2007. Planning of renewables schemes: Deliberative and fair decision-making on landscape issues instead of reproachful accusations of non-cooperation. Energy Policy 35. (5): 2692-2704.

Wolsink, M. and Breukers, S. 2010. Contrasting the core beliefs regarding the effective implementation of wind power. An international study of stakeholder perspectives. Journal of Environmental Planning and Management 53. (5): 535-558. 
